UDK: 111 Hartmann, N.

\title{
Utemeljenje »nove ontologije « u filozofiji Nicolaia Hartmanna kao kritika necjelovitih filozofskih sustava
}

\author{
Strahinja Đordević*
}

\begin{abstract}
Sažetak
Cilj je ovoga rada razmatranje značenja ontologijskog doprinosa Nicolaia Hartmanna, kao i ukazivanje na posljedice njegova utemeljivanja »nove ontologije", koje se mogu shvatiti kao izravna kritika nekih, do njegova vremena izuzetno zastupljenih filozofskih stajališta, ali i novih tendencija koje su eskalirale u filozofskim krugovima u razdoblju u kojem taj autor stvara. U Hartmannovu djelu »Novi putevi ontologije «nailazi se na tumačenje realnog svijeta, koje se izvodi uz pomoć slojeva i kategorija bivstva. Po njegovu shvaćanju, pogreške mnogih, u njegovo vrijeme aktualnih sustava, sastoje se u davanju prednosti jednomu sloju realnog svijeta na štetu drugih, što je za posljedicu imalo razvitak redukcionističkih gledišta. Osim redukcionizma, davanje prednosti jednomu sloju u odnosu na druge može rezultirati i teleološkim zatvaranjem, koje zastupaju oni koji prednost daju najvišemu odnosno duhovnomu sloju. Jedna je od posljedica sukoba između spomenutih gledišta neslaganje u vezi s pitanjem što čini određeno filozofsko stajalište prihvatlivim, pa tako nastaje prijepor oko toga treba li pri prihvaćanju jednog filozofskog sustava u prvi plan staviti relevantnost ili egzaktnost. Budući da taj sukob neizravno nastaje iz davanja prednosti jednomu sloju u odnosu na ostale slojeve realnog svijeta, čini se da su oba gledišta pogrešna.

Ključne riječi: Nicolai Hartmann, realni svijet, bivstvo, ontologija, slojevi, kategorije, zakoni
\end{abstract}

\section{Uvod}

Filozofiju kraja 19. i početka 20. stoljeća najbolje dočarava jedna specifična slika njezine rastrganosti između nastavljača idealističkih učenja i sve čvršćih redukcionističkih težnji novih filozofskih pravaca. Ono, naizgled zajedničko u objema strujama svojevrsno je svođenje postojećeg svijeta na jedno od njegovih određenja. Nesumnjivo je da su ti zahtjevi predstavljali potencijalnu opasnost

* Strahinja Đorđević, mag. fil., doktorand na Filozofskom fakultetu Sveučilišta u Beogradu. Adresa: Čika Ljubina 18-20, 11000 Beograd, Srbija. E-pošta: boostergold@hotmail.rs 
za svaki pokušaj utemeljenja bilo kakve stabilnije ontološke doktrine. Stanje je bilo takvo dijelom zbog prividno primamljivijih alternativa, a djelomično i zbog mogućeg nedostatka inovativnosti, za koji se činilo da postoji kada je to područje u pitanju. Nicolai Hartmann (20. veljače 1882. - 9. listopada 1950.), baltičkonjemački filozof, nekadašnji pripadnik marburške škole novokantovaca, a nakon toga sljedbenik fenomenologije, svojim radom pokušava »rehabilitirati« ontologiju, a po njegovu mišljenju i cjelovitost filozofije uopće.

Period u kojem on stvara prva je polovica 20. stoljeća, a njegova djela, kao što su Novi putevi ontologije, Osnovne crte jedne metafizike spoznaje i Estetika smatraju se izuzetno važnim tekstovima za povijest filozofije. Međutim, njegovu važnost najvjerojatnije ne treba tražiti samo u kontekstu historijske komparativne analize njegova stvaralaštva (primjerice uspoređivanje njegovih stavova s drugim filozofima njegova vremena), nego i u aktualnosti pitanja kojima se bavio. Iako je, kako je navedeno, u početku bio novokantovac, kasnije se okrenuo kritičkomu realizmu, u okviru kojeg se često smatra najznačajnijim predstavnikom. Na njegovu je filozofiju u velikoj mjeri utjecao fenomenološki zahtjev za okretanje »ka samim stvarima«. Može se reći da je Hartmannovo interesiranje za te pravce mišljenja, kao i poznavanje njihovih doktrina njemu pomoglo pri izgradnji vlastite filozofske pozicije. S obzirom na to da je njegov doprinos nezanemarljiv i u oblastima kao što su etika, estetika i gnoseologija, nerijetko se smatra i posljednjim sistematičarem. Hartmann svojim zahtjevom za ponovnim bavljenjem ontologijom postaje karakterističan po tome što je jedan od rijetkih filozofa koji se u prvoj polovici 20. stoljeća primarno interesirao za to filozofsko područje.

Hartmannova fasciniranost ontologijom djelomično proizlazi iz činjenice da u njegovo vrijeme ono što se ranije smatralo prvom filozofijom praktički ne postoji. Kako je zapazio, nakon Christiana Wolffa, ${ }^{1}$ ontologija je pala u dubok san. Hartmann je svakako pokušao probuditi uspavanoga džina i vratiti mu izblijedjelu slavu. ${ }^{2}$

Hartmann uočava veliko misaono razilaženje koje se manifestira u sukobu između realista i idealista. Smatra da se kritikom i uočavanjem razlike između tih dvaju gledišta može razumjeti i povijesni raskol, čiji je uzrok odabir različitih pristupa pri određivanju »bivstva«. Kao što je već prethodno bilo spomenuto, nerijetko je i da se Hartmann uzima za predstavnika pravca takozvanoga kritičkog realizma, čije je jedno od obilježja kritika idealizma i materijalizma, ali i samog realizma. To stajalište ne treba miješati s naivnim realizmom, koji je također imao brojne sljedbenike u Hartmannovo doba, ali ga je on odbacio zbog nezadovoljavajućeg, pojednostavljenog prikaza svijeta. Budući da je u prošlosti i sam pripadao nastavljačima idealističke tradicije, za razumijevanje njegova kritičkog realizma neophodno je raskrstiti s nekim od stavova koje zauzima Kantova filozofija, a i njezini nastavljači, osim bavljenja ontologijom.

1 Tvorac najpoznatijeg filozofskog sustava u razdoblju između Leibniza i Kanta od prvog preuzima i temelje svoje metafizike (Wolff-Leibnizov sustav).

2 Predrag Cicovacki, New Ways of Ontology - The Ways of Interaction, Axiomathes: An International Journal in Ontology and Cognitive Systems, 12 (2001), 159. 


\section{Obrat kopernikanskog obrata}

Za razliku od idealizma, koji subjekt i njegovu spoznaju postavlja kao okosnicu odredbe postojanja, Hartmann smatra da treba prihvatiti nov ontološki pristup čiji bi zadatak bio izmjena tog odnosa, to jest donošenje svojevrsnog novog obrata u promatranju odnosa subjekt-objekt.

»U suštini svake spoznaje leži da je usmjerena ne na sebe samu, već na svoj predmet. $\ll^{3}$ Taj obrat zapravo je kritika onoga kopernikanskog koji se susreće u filozofiji Immanuela Kanta i njegovih sljedbenika. Za razliku od njih, koji čovjeku pripisuju stvaranje predmeta svoje spoznaje, Hartmann zauzima stav da je bît već dana, a da se čovjekov zadatak sastoji isključivo u njezinu »prikupljanju«, a ne »stvaranju«. Dakle, čovjekove transcendentalne moći nisu »kreatori« objekta spoznaje, nego moć skupljanja pojava iz prirode kakve su one u njoj već dane. Subjekt je neposredno usmjeren k predmetu spoznaje, zato što je taj predmet objektivan, stoga i nije potrebno dodatno umjetno usmjerenje koje se naizravno nalaže kod Kanta. Takav pristup nije bio izuzetak. Mnogi Hartmannovi suvremenici također su prepoznali nedostatke transcendentalnog idealizma na koje je on pokušao ukazati.

Kao i Hartmann, oni ${ }^{4}$ su isto imali želju za bijegom iz neokantizma — za napuštanjem unutrašnjeg okvira svijesti i samorefleksije kao teoretskih temelja svojih filozofija. S osvrtom na imanenciju svjesnosti, s pozicije njegove realističke gnoseologije Hartmann im je otkrio da je gnoseološka relacija između subjekta i objekta također prava korelacija u okviru svijeta. ${ }^{5}$

Nije jasno na koji bi to način objekt (bivstvo, svijet) mogao ovisiti samo o subjektu, a to polazno stajalište vrlo je često uzimano kao činjenica u svim idealistički orijentiranim filozofskim postavkama. Prije će važiti da je ono što je ovisno o subjektu jedino spoznaja objekta, kojem naravno ne treba umanjiti važnost. Međutim, odmah treba postaviti pitanje: Kakva je to spoznaja? Je li ona uopće moguća? Treba imati u vidu da po Hartmannu realan objekt spoznaje nije neki neodređeni entitet konstituiran prostim nagađanjem i preambicioznim spekulacijama, nego njegova vrijednost leži baš u realitetu koji se iskazuje u svijetu koji spoznajemo, kao njegov čimbenik. Nepotrebno je reći da takva pozicija isključuje potrebu za utemeljenjem potencijalnih dvojakih vidova postojanja, kao što se, s druge strane, kod Kanta pojavljuje zahtjev za razgraničavanjem fenomenalnog i noumenalnog svijeta.

Međutim, što se događa s razlozima na temelju kojih se naizgled čini da je potreba za postuliranjem takve razlike nužna? Zar Kant nije opravdano uočio da je podjela neophodna zbog nespojivosti između onoga što je glavni konstituens

3 Nicolai Hartmann, Novi Putevi Ontologije, Beograd, 1973, 15.

4 Misli se na Maxa Schelera i Helmutha Plessnera, utjecajne njemačke filozofe, čije misli također karakteriziraju odbacivanje idealizma i prihvaćanje fenomenološkog pristupa.

5 Joachim Fischer, Nicolai Hartmann: A Crucial Figure in German Philosophical Anthropology Without Belonging to the Paradigm, u: Roberto Poli - Carlo Scognamiglio - Frederic Tremblay (ur.), The Philosophy of Nicolai Hartmann, Berlin, 2011, 84. 
takozvanog fenomenalnog i noumenalnog svijeta? Kojem od tih svjetova Hartmann odriče postojanje? Odgovor se krije u shvaćanju samog bivstva. Ono se ne može »razbiti« na cjeline ni na takozvane »svjetove«, makar i s ciljem traženja nekog nestabilnog ontološkog opravdanja koje bi subjektu bilo neophodno da prebrodi jaz između njega i same bîti objekta kojemu dolazi u susret. Čini se da je najveća slabost Kantove filozofije neopravdano uvođenje stvari po sebi, čija bi svrha bila svladavanje tog raskola, odnosno davanje mogućnosti postojanja objektu neovisno o »spoznajnoj proizvodnji« subjekta.

Što se tiče »svjetova« u kantovskom smislu te riječi, nema potrebe za pobijanjem postojanja jednoga od njih jer — poriču se oba! Nova ontologija ne ostavlja prostor za transcendenciju koja Kantu služi kao svojevrsna garancija održivosti njegova filozofskog sustava, ali ni transcendentalnost, u smislu kako je on shvaća, a koja, po Hartmannu, očigledno vodi u zablude, karakteristične za idealistički pogled na svijet. Transcendentalni idealizam može djelovati kao primamljivo stajalište, ali se susreće s velikim problemom kod uspostavljanja pravog odnosa između čovjeka i svijeta. Budući da je u takvom (idealističkom) stanju stvari ključan odnos između subjekta i predmeta njegove spoznaje (isključivo na način kako je on spoznaje), a ne njega i spoznavanja nečega što postoji i neovisno od njega, mora se zaključiti da ni transcendentalnost, čak ni »ogoljena« od bilo kakvih težnji prema transcendenciji, nema dovoljno dobar uvid u svijet realnih pojava izvan tog subjekta. Sve dok »robuje« idealističkim pretenzijama, transcendentalnost nema pravu moć raspoznavanja bivstva, jer čini se očiglednim da se bez uspostavljanja odnosa subjekt-objekt ne može ostvariti ni njegovo jasno shvaćanje, jer je ono, izgleda, ipak dano kao neovisno u odnosu na čovjeka. Po Hartmannu, transcendentalni idealizam nije održiv, ne samo zbog uvođenja transcendencije i stvari po sebi, nego i zbog »zanemarivanja « postojanja objekta neovisno o predmetu spoznaje subjekta.

Upravo u suprotstavljanju novokantovskom kategoričkom ograničenju bivstva na puko logičko-konceptualno određenje, fenomenološka reevaluacija premisa samog znanja, i još važnije, same mogućnosti spoznaje, omogućava Hartmannu da o ontološkim pitanjima razmišlja s nove tačke gledišta, oslobođen od zgrčenih ograničenja »čiste misli«. ${ }^{6}$

Dakle, ono što gradi Hartmannovu novu ontologiju je nov način sagledavanja svijeta, gdje on više neće biti tumačen intersubjektivno, nego će se njegovo postojanje prihvatiti kao realno. To znači da subjekt gradi spoznaju o tom realnom objektu, a ne »stvara « ga vlastitim transcendentalnim sposobnostima, uz pomoć kategorija i čistih formi osjetilnosti. Idealizam je sa sobom donio jednu neopravdanu prenaglašenost subjekta i potpuno zanemarivanje bilo čega što ne bi bilo predmetom subjektove spoznaje. Međutim, s druge strane, svijet nikako ne može biti posve subjektivan. Takvo bi shvaćanje u krajnjoj liniji moglo

6 Nicoletta Ghigi, Phenomenology and Ontology in Nicolai Hartmann and Roman Ingarden, u: Roberto Poli — Johanna Seibt (ur.), Theory and Applications of Ontology: Philosophical Perspectives, London, 2010, 331. 
dovesti čak i do opasnosti od određene vrste solipsizma. Baš zbog takvih očitih nedostataka novokantovske filozofije Hartmann ističe potrebu za okretanjem k fenomenološkoj analizi.

U čemu bi se sastojala ta analiza? Prije svega, u izdvajanju samih pojava koje su realno dane u svijetu, a njihovo spoznavanje u cijelosti znači i spoznavanje samog bivstva. Ono ne bi više trebalo promatrati na način kako se to činilo u okviru nekih tradicionalnih filozofija, kao što su one koje zastupaju metafizički realizam, koje ga shvaćaju kao neki entitet čije je postojanje »izvan ovoga svijeta . Veoma je često kao temeljno obilježje bivstva navođena i njegova nespoznatljivost. To bi značilo da čovjek nema nikakve mogućnosti njegove spoznaje niti za života dolazi u neposredan odnos s njim. Osnovna kritika takvih težnji odnosi se na apsurdnost ontologije u čijem bi središtu bilo nešto o čemu se ne može imati nikakva spoznaja. »Ontologija je dakle metafizika čija je pažnja usmjerena na intelektualno dostupne entitete. $\ll^{7}$ Metafizički realizam tvrdi da postoji nešto o čemu ne bi imalo nikakva smisla išta misliti ili govoriti po samoj definiciji. Budući da u tom slučaju nije uopće riječ o nečem realnom, nego o misterioznom entitetu koji je u određenom raskolu ne samo s čovjekovim razumskim mogućnostima, nego i sa samim čovjekom. Drugim riječima, takvo »bivstvo« ne samo da nije ni u kakvoj vezi sa subjektom, nego se ono ne može smatrati ni objektom spoznaje, baš zbog navodnog svojstva nespoznatljivosti. Očigledno je da ako nešto nije potencijalni objekt spoznaje, to jasno govori o tome da taj entitet mora na neki način biti izdvojen iz svijeta. Ono što ne može biti objekt nije ni u svijetu, što bi značilo da ni bivstvo nije dio svijeta. Ako je tako, onda govorimo o bivstvu koje je apsolutno irelevantno za ljudsko postojanje i indiferentno prema svijetu.

S druge strane, ako pak postoje neki zastupnici takva viđenja bivstva koji svijet ipak smatraju njegovim dijelom, iako ni subjekt ni objekt nisu njegovi konstituenti, znači li to da on nije dio samog sebe? Očigledno je da i subjekt koji spoznajnim aparatom dolazi do pojava iz svijeta i objekt koji taj subjekt spoznaje jesu dijelovi svijeta. A ako se u sklopu bivstva nalazi i svijet, jasno je da bi i oni trebali potpadati pod njega, a to po tom filozofskom stajalištu nije slučaj. U slučaju prihvaćanja takvih premisa, treba zaključiti da je metafizički realizam neodrživo stajalište jer govori o stvarima za koje sam kaže da su nespoznatljive, kao i zbog ontološke nerelevantnosti koje nosi njegovo odvajanje od prirodnog svijeta, ali i zbog proturječja koja nastaju ako njegovi zastupnici tvrde da je svijet dio bivstva.

To je doduše samo jedan od primjera monističkih težnji u filozofiji, koji proizlazi iz zablude čije se podrijetlo može tražiti u tumačenju nekog specifičnog dijela bivstva kao njegove cjeline. Koji je dio neopravdano uzeti za njegovo cjelokupno predstavljanje, varira od pravaca i njihovih pojedinačnih zastupnika, ali je svima njima zajednički taj propust.

Zatim, stara ontologija je zavisila od stanovišta filozofa prema pitanju »osnove svijeta i kao takva je bila materijalistička ili idealistička. Hartmann, međutim, smatra da nova, kritička ontologija treba da u polazištu bude neovisna od ovog protivstava, 
»S ove strane njega«; jer ontologija se bavi bićem kao bićem, pa za njen način postavljanja problema »nije važno da li postoji neki svjetski temelj, da li on ima oblik inteligencije ili ne, da li je izgradnja svijeta smislena, a njen proces svrhovito usmjeren. To u karakteru bića ne mijenja mnogo $\ll^{8} .9$

To može biti posljedica određenog duha vremena ili možda izvjesno intelektualno pomodarstvo, ali bez obzira na razloge nastanka, takvim pravcima treba posvetiti pažnju, ne toliko zbog njihova povijesnog značenja za razvoj filozofske misli ni zbog neke pretjerane inovativnosti, nego zbog uviđanja njihove međusobne isključivosti. $\mathrm{O}$ čemu je zapravo riječ? Ne postoji ništa što bi u filozofskom smislu moglo spojiti jednog materijalista i jednog idealista osim, naravno, zanemarivanja onoga što po njima ne leži u temelju svijeta. Kao što je rečeno, mnogi od tih pravaca tretiraju samo jedan ili nekoliko vidova bivstva kao njegovu cjelinu, a svako učenje koje obilježavaju takve težnje kritikom sebi suprotstavljenih stajališta zapravo daje pomoć za ostvarivanje pravilnog razumijevanja bivstva. Jedino što treba učiniti jest obratiti pažnju na ontološke nedostatke koje oni ukazuju jedni drugima, da bi se vidjelo kako svaka od njih zapravo posjeduje jednu nepotpunu sliku bivstva, koja se upotpunjuje sintezom njihovih ispravnih zapažanja o njemu, a »čisti« odbacivanjem spornih.

\section{Metafizička struktura svijeta}

Budući da je, slijedeći trag nove ontologije, postalo jasno da je bivstvo složena cjelina, tijek misli vodi do jednog od najvažnijih pitanja: U čemu se ono sastoji? Hartmann dijeli realnost na četiri sloja: anorganski, organski, duševni i duhovni. Treba odmah napomenuti da je za razumijevanje raslojavanja realnog svijeta neophodno pravilno razumijevanje kategorija bivstva koje treba razlikovati od kategorija spoznaje. U prošlosti se uzimalo zdravo za gotovo da su za spoznaju kategorija bivstva neophodne kategorije spoznaje, međutim, taj se odnos može osporiti. Po Hartmannovu tumačenju, kategorije spoznaje one su koje se spoznaju pomoću kategorija bivstva, refleksijom o spoznajnoj funkciji.

»I unutar oblasti legitimne primjene neke spoznajne kategorije stalno postoje granice njene nadležnosti, pošto se ona i sadržinski samo djelomično poklapa s odgovarajućom bivstvenom kategorijom. «10 Dodatnu konfuziju unosi takozvana kategorijalna diferencija, odnosno granica poklapanja tih kategorija, međutim Hartmann je ne smatra relevantnom za gonetanje problema realnog svijeta. Kategorije bivstva već su date, samo je njihova spoznaja uvjetovana subjektom te tu treba tražiti podrijetlo zablude o njihovoj nužnoj povezanosti s kategorijama spoznaje. Što se tiče njihove prisutnosti u određenim slojevima, kao što će se vidjeti, neke se mogu javljati samo u jednom, a neke u više slojeva, a postoje i

8 Nicolai Hartmann, Zur Grundlegung der Ontologie, Berlin, 1965, 39.

9 Vuko Pavićević, Hartmanov Prilog Ontologiji, u: Nicolai Hartmann, Novi Putevi Ontologije, Beograd, 1973, 130.

10 Nicolai Hartmann, Novi Putevi Ontologije, 115. 
one koje se susreću u svim četirima slojevima. Takve se kategorije nazivaju fundamentalnim.

Ove vrste su kategorije: jedinstvo i raznolikost, suglasnost i protivnost, suprotnost i dimenzija, diskrecija i kontinuitet, supstrat i relacija, element i sklop. Isto tako ovdje spadaju: forma i materija, unutrašnje i spoljašnje, determinacija i dependencija. Također se ovdje mogu priključiti i kvalitativne suprotnosti kao što su identitet i raznolikost, općenitost i individualnost; isto tako i modalne kategorije: mogućnost, stvarnost, nužnost i njihovi negativni suprotni članovi. Svaka od ovih kategorija prolazi kroz cijeli slojni niz i pri tome se preobražava od sloja do sloja. ${ }^{11}$

Prvi je sloj realnosti anorganski, odnosno takozvani materijalni sloj. Što spada pod taj sloj? Kao što njegovo ime sugerira, riječ je sloju koji obuhvaća čitav anorganski svijet, odnosno sve fizičke predmete, pojave, procese i dr. U okviru njega po prvi se put javljaju neke od fundamentalnih kategorija bivstva tjelesnog svijeta. Kategorije su tog sloja prostor i vrijeme, supstancijalitet i kauzalitet, proces i stanje, dinamički sklop i ravnoteža itd. Anorganski je i najrašireniji sloj realnog svijeta, a ujedno daje $\mathbf{i} \gg g r a đ u$ « ostalim slojevima.

Kako Hartmann u svojem dijelu Novi putevi ontologije dalje navodi, iznad anorganskog je organski sloj, koji se odnosi na ono »živo« i sve biološke procese u njemu. Tek se od tog sloja može govoriti o živom svijetu odnosno živim bićima. U njemu se pojavljuju i izvjesne nove kategorije bivstva (o samom pojmu novuma bit će riječ nešto kasnije) kojih nema u materijalnom sloju. Neke su od tih kategorija: organski sklop, prilagođenost i svrsishodnost, samoregulacija, razmjena materije, izrođavanje, samooblikovanje, konstantnost vrste i dr. Važno je napomenuti da anorganski i organski sloj dijele neke određene kategorije, kao što su prostor i vrijeme, a razlikuju se po nekim drugim kategorijama. Još je jedno njihovo zajedničko obilježje i mogućnost spoznaje neposrednim osjetilnim putem. Svako tko ima ispravan osjetilni sustav može, u manjoj ili većoj mjeri, imati neposredno iskustvo anorganskog i organskog svijeta. U prošlosti se neopravdano smatralo da kombinacija tih dvaju slojeva čini takozvani realan svijet, međutim, kada se zađe u nešto dublju fenomenološku analizu, postaje jasno da je to gledište ipak neodrživo. Je li sve što postoji vezano uz ono što se nalazi u anorganskom i organskom sloju? Ako je tako, onda je potrebno razjašnjenje mnogih nedoumica koje se javljaju pri prihvaćanju takva stava, od kojih je jedna od najvažnijih ona koja se tiče određenih čovjekovih htijenja i želja koje se ne mogu puko svesti na zadovoljenje osjetilnih potreba. Naravno, tu se ne poriče čovjek kao fizičko i biološko biće, samo se napominje da postoje i drugi elementi neophodni za svrstavanje u ono što se naziva realnim bivstvom. Dakle, prva dva sloja nisu dovoljna za određivanje realnog bivstva u cijelosti.

Zbog toga se poslije prva dva, osjetilno dostupna sloja, javlja treći, duševni (ili psihički) sloj bivstva, koji se vezuje uz određene psihičke procese. Granica između organskog i duševnog sloja je takozvana psiho-fizička granica, koju karakterizira prekid preformiranja kategorija bivstva. Nove kategorije, koje se javljaju kao dio 
duševnog sloja bivstva, jesu: akt i sadržaj, svjesnost i nesvjesnost, zadovoljstvo i nezadovoljstvo. Ne bi trebala nikomu biti sporna činjenica da svaki čovjek ima određenu duševnu prirodu, koja se očituje kao različita u odnosu na materijalni svijet (u širem smislu — misli se na spoj anorganskog i organskog). Neke njegove funkcije jednostavno se ne mogu svesti na puku kombinaciju njegove tjelesne prirode i izvjesnih bioloških procesa koji se u njemu odvijaju. Potreba za hranom može se, recimo, tumačiti bez uvođenja duševnog sloja realnog svijeta, ali to isto ne može vrijediti za niz drugih potreba, kao što je ona za sigurnošću, umanjenjem duševne boli ili, recimo, suosjećanjem.

Četvrti sloj Hartmann naziva duhovnim. Iako je najmanje raširen, on je bez sumnje najsloženiji sloj, ali i najteže objašnjiv i najmanje neposredno jasan. Samo neke od kategorija bivstva (osim onih fundamentalnih), kao što je vrijeme, opet se javljaju u tom sloju. I tu postoji javljanje novih kategorija bivstva, kao što su misao, vrednovanje, htijenje, sloboda, spoznaja, osoba. Taj je sloj »zaslužan« za takozvani ljudski duh kao ono što izmiče svakoj fizičkoj ili psihičkoj definiciji, a ponovo ih na sofisticiran način nadvisuje.

Duh ne stoji izvan realnog svijeta, on tom svijetu sasvim pripada, ima istu vremenitost, isto nastajanje i prolaženje kao i stvari i živa bića. Ukratko, on ima isti realitet. Samo zbog toga on može i djelovati u ovom svijetu i iskusiti njegova djelovanja na sebe, imati u njemu svoju sudbinu i svoje polje djelovanja. ${ }^{12}$

Iako se pojedini mislioci možda mogu složiti s činjenicom da čovjek nije samo materijalno, nego i psihičko biće, ali da istodobno postojanje duhovnog sloja uzima kao suvišno. Takav stav ne djeluje utemeljeno jer se čini da psihički sloj nije dovoljan za obuhvaćanje složenosti čovjekova bića. Glavna je razlika između duševnog i duhovnog sloja ta da se prvi vezuje isključivo uz konkretni subjekt. Dakle, psihički sloj karakterizira svojevrsna individualnost, odnosno on nosi određenu subjektivnu neovisnost. Nečiji psihički doživljaji isključivo su njegovi i ne postoji nikakva mogućnost dijeljenja s drugima. Primjerice, nezadovoljstvo neke određene osobe samo je njezino nezadovoljstvo te ga stoga ne može »dijeliti« s drugima. To vrijedi čak i u slučaju postojanja još jednog nezadovoljnog čovjeka pored njega jer oni ne dijele isto nezadovoljstvo. Za razliku od trećeg sloja, duhovni je sloj nadindividualan, što znači da se on ne odnosi na nekog specifičnog pojedinca, nego na cjelokupnu ljudsku zajednicu. Stoga je religija dobar primjer ukazivanja na ono što se javlja isključivo u duhovnom sloju. Iako počiva na svojstvenoj individualnosti, ona se očituje kroz zajednički duh.

Jedan od važnijih uvida koji slijedi iz raslojavanja realnog svijeta razlika je koja se javlja između kategorije vremena i prostora. Premda se oni u idealističkoj filozofiji uvijek promatraju kao neodvojivi jedno od drugoga u vidu čovjekovih apriornih moći, kod Hartmanna im se odriče ne samo postojanje prije svakog iskustva, nego i javljanje u istom broju slojeva realnog svijeta, što ih čini fundamentalno drugačijima i odriče im ulogu korelata koja im je u prošlosti tako samouvjereno pripisivana. 
Istinske oznake realiteta nisu vezane za kategorije prostora i materije, već za kategorije vremena i individualiteta. Prostor i vrijeme nisu ontološki jednako vrijedne kategorije: vrijeme je mnogo fundamentalnije od prostora. ${ }^{13}$

Pošto je ustanovio da se prostor, kao dio isključivo materijalnoga (u širem smislu) svijeta, javlja samo u anorganskome i organskome sloju, a da se vrijeme, osim javljanja u ovim dvama slojevima, pojavljuje i u duševnome i duhovnome sloju, Nicolai Hartmann s sigurnošću odbacuje idealističko shvaćanje vremena i prostora. Dakle, on zastupa stav da gledište koje prostor i vrijeme svodi samo na produkt subjektova uma i nužno stavlja u vezu kao čiste osjetilne opažaje njih ne shvaća na pravi način. Razlog za Kantovo navodno nerazumijevanje vjerojatno treba tražiti u njegovu uvođenju razlike između unutrašnjega i vanjskoga osjetila, koje on promatra kao isti »aparat«, što dalje implicira da nema aficiranja bez njihova zajedništva. Posljedice ovoga gledišta takve su da se prostor i vrijeme promatraju kao neuništivi, međusobno ovisni entiteti, strogo vezani uz subjektovu transcendentalnu moć.

Hartmann je, napustivši učenje novokantovaca iz Marburga, odbacio i idealističke pretenzije usmjerene $\mathrm{k}$ ovakvu viđenju prostora i vremena. To mu je i omogućilo da odbaci gledište o njihovoj nužnoj povezanosti. Dakle, budući da prostor i vrijeme nisu isključivo subjektivna svojstva i dijelovi jednog te istog »osjetila«, ne postoji potreba da se oni nužno promatraju kao »dvije strane jedne te iste medalje «.

Nakon razmatranja raslojavanja realnoga svijeta to se jasnije uočava jer se ne naslućuje nikakav razlog zašto bi se prostoru pridavala mogućnost javljanja izvan anorganskoga i organskoga sloja odnosno u duševnome i duhovnome sloju, a jasno je da se vrijeme, kao kategorija, ovdje javlja. »Svi realni entiteti su stoga vremenski entiteti. «14 Bez ikakve dileme, ako se prihvati raslojavanje svijeta kakvo nudi Hartmann, vremenu bi se morala pripisati temeljna uloga zato što se u njemu, pored dvaju nižih slojeva, ostvaruju i duševni i duhovni (odnosno cjelokupan) realitet, što naravno ne znači da bi prostoru trebalo odricati nužnost kao jednoj od najvažnijih kategorija tjelesnog svijeta. Tu bi se možda trebalo postaviti pitanje: Čime su točno određene relacije koje se javljaju između kategorija kao dijelova izvjesnog sloja bivstva i cjelokupnog realnog svijeta uopće?

Da bi se bolje shvatili takvi i slični odnosi između kategorija bivstva realnog svijeta, pojavljuju se izvjesni zakoni koji se mogu primijeniti na njihovo javljanje u okviru različitih slojeva. Oni se nazivaju zakonima raslojavanja. Jedan od njih bio bi zakon vraćanja (rekurencije) — prvi zakon raslojavanja koji se odnosi na ponavljanje određenih kategorija u višim slojevima bivstva.

To znači da se jedna te ista kategorija može javljati u nekoliko slojeva. Važno je napomenuti da se taj zakon odnosi isključivo na ponavljanje kategorija iz nižih slojeva u višima, nikada obrnuto. Dakle, jedna kategorija iz anorganskoga može

13 Isto, 23.

14 Roberto Poli, Ontology: The Categorial Stance, u: Theory and Applications of Ontology: Philosophical Perspectives, Roberto Poli - Johanna Seibt (ur.), London, 2010, 2. 
se pojaviti, recimo, u organskom sloju. Međutim, kategorija organskog sloja ne može se ponoviti u anorganskom sloju. Zakon rekurencije možda se najbolje može objasniti na već spomenutom primjeru vremena koje se kao kategorija javlja u svim četirima slojevima bivstva, što znači da je ono sadržano još u prvom, anorganskom sloju, a da je ponavljanje ostvareno u organskom, duševnom i duhovnom sloju. To također znači da vrijeme kao kategorija prožima čitav realni svijet, a već je primijećeno da isto ne vrijedi i za prostor, koji se javlja samo u neorganskom i organskom sloju. Takvo shvaćanje prostora donekle je drugačije od sadržaja većine filozofskih postavki, imajući u vidu da se, u okviru realnog svijeta, status prostora rijetko dovodio u pitanje. Iako je, uzimajući u obzir njegov filozofski stav, jasno da Hartmann nema nikakvih metafizičkih pretenzija, na prvi pogled može zbuniti to što prostoru nije pripisano postojanje u cjelokupnom realitetu svijeta. U pitanju je samo prividna zabuna jer se u pojedinim filozofskim sustavima duhovni i duševni sloj nisu uzimali kao dijelovi realnog svijeta.

Osnovna greška ovog načina promatranja stvari leži u tome što se u njemu zamjenjuje realitet s materijalnošću. Zato se vjerovalo da se realitet ograničava na prostornost. Ali onda ljudske sudbine, povijesna stanja i događanja također ne bi bili realni; a time bi se učinilo nerealnim upravo ono što se najjače osjeća kao realitet. ${ }^{15}$

Budući da je očigledno da takvo shvaćanje prostora ne mora vrijediti u novoj ontologiji, iz toga slijedi da raširenost kategorije prostora samo na određen dio realnog svijeta ne samo da nije neodrživo, nego posjeduje prednost u odnosu na alternativnu opciju. S druge strane, treba primijetiti da je to u suprotnosti s idealizmom, po kojem prva dva sloja nemaju objektivnu realnost, ali se prostor kao čista forma osjetilnosti javlja baš ondje gdje joj Hartmann odriče prisutnost. Dakle, i tu se može nedvosmisleno prikazati nekompatibilnost učenja »nove ontologije « i idealističke filozofije.

Drugi je zakon raslojavanja zakon modifikacije, odnosno promjene. On se javlja pri promjeni kategorija tijekom njihova prijelaza iz nižih slojeva u više. Dobar primjer za to bila bi različitost jedne te iste kategorije koja se ostvaruje preformiranjem, koje se događa na prijelazu između anorganskog i organskog bivstvenog sloja. »Svaka od ovih elementarnih kategorija pri svom ponovnom vraćanju iz sloja u sloj prima nešto od svojevrsnosti sloja. I to je sasvim razumljivo, jer svaki bivstveni sloj ima svoj vlastiti sistem kategorija, čiji članovi stoje u najužoj vezi.«16

Za treći zakon raslojavanja uzima se takozvani zakon novuma. U slučaju kada bi promjena određenih svojstava neke kategorije, koja se javlja u drugom zakonu raslojavanja, bila jedini čimbenik koji čini razliku između slojeva bivstva, pitanje je bi li oni uopće postajali u istom smislu kakvi zapravo jesu. Naime, Hartmann primjećuje da se u višim slojevima pojavljuju određene kategorije koje se ne javljaju u nekim nižim slojevima. Tu zakonitost on naziva novumom. Novum bi zapravo bio isto što i emergencija - pojavljivanje novih elemenata (u

15 Nicolai Hartmann, Novi Putevi Ontologije, 22.

16 Isto, 61. 
tom slučaju kategorija bivstva) pri prijelazu iz nižih u više slojeve. Tu je, dakle, u pitanju pojavljivanje jedne sasvim nove kategorije koja nema veze ni s jednom drugom koja se javljala u nižim slojevima.

Samoregulacija i ponovno samoformiranje predstavljaju neospornu novost prema fizičkom procesu i njegovoj matematičko-kvantitativnoj zakonitosti. Akt i sadržaj duševnog života isto tako su novost prema organskim procesima; a novost prema njima znače sadržaj duhovnog života, kao jezik, znanje, pravo, moral i tako dalje, koji postoje odvojeno od duševnog akta pojedinca i povijesno se prenose. ${ }^{17}$

Zakon novuma u specifičnom je, ovisnom odnosu sa zakonom rekurencije:

Zakon vraćanja i zakon Novuma obrazuju zajedno obrazac (Formtypus) kategorijalnog slojevanja. Uzeti za sebe, ostaju jednostrani. Svaki od njih je izraz jedne strane odnosa slojeva: od vraćanja zavisi povezanost, a od Novuma različitost slojeva. ${ }^{18}$

Posljednji, četvrti zakon raslojavanja tiče se njihova međusobnog odnosa i nosi naziv zakon distance između slojeva. Taj zakon najbliže oslikava samo bivstvo, prikazivanjem ostvarivanja njegove pluralističke prirode. Naime, tu u prvi plan dolazi razvijanje individualnih slojeva, neovisno jednih od drugih ${ }^{19}$. Ta neovisnost ogleda se u jasnim granicama između anorganskog i organskog, organskog i duševnog, kao i duševnog i duhovnog. Dakle, ne postoji nikakav, uvjetno rečeno, kontinuitet između slojeva realnog svijeta.

Uzlazni niz bivstvenih formi ne obrazuje kontinuitet. Pošto na određenim usjecima u nizu istodobno nastupa (umeće se) kategorijalni Novum na mnogim kategorijama, bivstveni slojevi se jasno odvajaju jedan od drugog. Ta odvojenost predstavlja fenomen distance (odstojanja) slojeva koji je karakterističan za njihov poredak. ${ }^{20}$

\section{Sukob prividno relevantnog i egzaktnog viđenja svijeta}

Ono što se u djelu Novi putevi ontologije uočava dva su dijametralno suprotna pokušaja promatranja svijeta i postavljanja njegovih temelja. Prvo viđenje bilo bi ono za koje se može reći da vuče korijene iz određenih vrsta tradicionalnih metafizika, a karakterizira se promatranjem svijeta »odozgo«. To bi značilo da je cijelo bivstvo nošeno najvišim odnosno duhovnim slojem, a da se ostali slojevi pojavljuju isključivo kao slučajni. Takvo gledište Hartmann naziva teleološkim, zbog uvjetovanja nižih slojeva onim najvišim. Problem je s takvim shvaćanjem realnosti taj što, u slučaju takve ovisnosti postoji zahtjev za prihvaćanjem apsolutnog nedostatka slobode. Drugim riječima, ako sve "polazi odozgo« i ovisno je o najvišem sloju, onda niži slojevi bivstva postoje samo kao njegova predodređena očitovanja. U ranijim filozofskim sustavima često se moglo naići na takav vid

17 Isto, 62.

18 Isto, 67.

19 Oni jesu ovisni u smislu koji se javlja u zakonu materije i slobode, ali samo uvjetno. Kada već postoji niži sloj, kao davalac neophodne građe, viši su slojevi apsolutno neovisni o njemu.

20 Isto, 63. 
zatvaranja, a najčešće se problem potencijalnog nedostatka slobode nadomještao prividno proturječnom vezom između nje i kauzalnosti. Hartmann tvrdi da ne postoji razlog zašto bi se zastupalo takvo »podređivanje«, makar u pitanju bio i najviši sloj realnosti. »Tu je riječ o predrasudi postulata jedinstva i prekoračenja granice: metafizičari hoće da imaju koliko je god to moguće jedinstven svijet i hoće da kategorije jednog sloja prenesu na sve slojeve. $\ll^{21}$

Međutim teleološko zatvaranje nije jedini primjer lošeg razumijevanja prirode svijeta. Naime, postoji, u Hartmannovo vrijeme popularno mišljenje, koje obrće tradicionalno metafizičko viđenje svijeta naopako. Riječ je o idejama koje su postale aktualne tijekom 19. stoljeća i zadobile primat kao puke činjenice postojanja. Proizvod je takvih pretenzija redukcionizam, odnosno bezuvjetna "prevlast « nekog od nižih slojeva nad ostalim slojevima. Svakako, »najteži je slučaj« te vrste fizikalizam, čija popularnost od Hartmannova vremena do danas doduše opada, ali još ne prestaje biti aktualno »filozofsko« stajalište. Fizikalisti uzimaju prvi sloj kao temelj postojanja i sve ostale slojeve promatraju kroz njegovu prizmu. Dakle, anorganski sloj tu se javlja kao nosilac svijeta, a ostali su slojevi samo njegova »nadogradnja«. Argument takvomu stajalištu bio bi taj da se sve ono što se javlja u organskom, duševnom ili duhovnom sloju može svesti na anorganski. Jasno je zašto je to gledište tako primamljivo, ako se uzme u obzir da je fizički svijet ${ }^{22}$ nešto u što se može imati najlakši neposredan uvid. Budući da ostali slojevi (naročito ne-prostorni) nisu čovjeku očigledno dati, postoji neka vrsta odbijanja prihvaćanja njihova značenja za realnost. Tako će zastupnici fizikalizma olako odbaciti metafiziku kao besmislicu jer ne govori o stvarima o kojima se može imati neposredan empirijski uvid. Neke druge discipline, čiji sadržaj posjeduje mogućnost verifikacije, ${ }^{23}$ fizikalisti će također svoditi na fiziku jer nju vide kao jedino područje s jasnim uvidima u realnost.

Naravno, najniži i najviši sloj nisu jedini kojima je kroz povijest davana prednost u odnosu na ostale slojeve. U prošlosti je dosta prostora bilo posvećeno biologizmu, koji organske procese kod čovjeka (i drugih živih bića) vidi kao glavni pokretač njegova djelovanja. Postojali su i brojni pokušaji objašnjavanja čitavog svijeta evolucionističkim teorijama, čiji je cilj bio pokazati apsolutnu ovisnost svih bića i njihovih postupaka o njihovim organskim obilježjima. Nesumnjivo je da te teorije više ne zaokupljaju toliko prostora kao nekada, ali ne bi se moglo reći da su sasvim »iščeznule«. Isto kao što se biologisti oslanjaju na ulogu organskog sloja kao nosioca prirode, slično tako psihologisti grade svoj stav prema duševnom sloju. Razlika je u tome što u duševnom sloju »iščezava« kategorija prostora, što je itekako važno u pogledu razdvajanja obilježja datih stajališta.

21 Isto, 79.

22 Može se koristiti kao sinonim za anorganski sloj, iako se i organski sloj uvjetno može smatrati fizičkim.

23 Verifikacija je stajalšte koje za smislene uzima samo one iskaze koji posjeduju neposrednu istinosnu vrijednost pa se na taj način mogućnost realnog postojanja pridaje isključivo sadržaju takvih iskaza. Jednostavno rečeno, verifikacija u obzir uzima samo tvrdnje koje mogu biti provjerene uz pomoć još temeljnijih tvrdnji, neposrednim empirijskim uvidom odnosno iskustvom. 
Psihologizam svojim odbacivanjem prostornih dimenzija kao esencijalnog svojstva za ostvarivanje slike o bîti svijeta velikim dijelom odbacuje i oslanjanje na ono što je naizgled najsigurnije i upušta se u područje »smanjene evidencije«. Iako se sigurnost u okviru psihologizma smanjuje, ono što se naizgled povećava je relevantnost. U tome upravo leži »bitnost « viših slojeva. Jasno je da se prijelazom iz nižih u više pojavljuje mnogo veći broj pitanja o svijetu i da je mnogo veći razmjer nemogućnosti razumijevanja, ali nepobitno je da nam sadržaj viših slojeva djeluje itekako relevantniji od nižih. Uvijek će se činiti da organski sloj može pružiti veću relevantnost za naše shvaćanje bivstva od anorganskog. Isto tako, duševni dio kao da nadvisuje organski po relevantosti, zbog već spomenutih razlika. Već kod psihologizma ta ideja uzima maha, međutim i on je u biti redukcionistički, kao i fizikalizam i biologizam prije njega, jer bez obzira na to što realnost svodi na naizgled relevantniji sloj u odnosu na druge (duševni), on se ponovo susreće sa sličnim problemima. To znači da nijedan od datih slojeva ne smije imati primat u odnosu na druge, jer se uzimanjem jednog od prva tri sloja za esenciju bivstva susrećemo s opasnošću od redukcionizma odnosno teleološkog zatvaranja, a u slučaju prihvaćanja najvišeg, duhovnog sloja.

\section{Zaključak}

U sukobu između relevantnosti, koja se javlja u višim, i egzaktnosti, koju pružaju niži slojevi, treba tražiti i uzrok podjela koje se javljaju u današnjoj filozofiji. Mnogi suvremeni mislioci odbijaju uzeti u obzir sve vidove bivstva, najvjerojatnije iz straha od izlaženja izvan okvira sigurnosti osjetilnog ili psihičkog svijeta. Sigurno je da se u slučaju prihvaćanja takva stava izbjegavaju neka izuzetno bitna ontološka pitanja. Dobivena je sigurnost, ali pod koju cijenu? Netko može ići i toliko daleko da postavi jedno kontroverzno pitanje: Je li to zapravo filozofija? S druge strane, oni koji se usredotočuju na relevantnost vrlo često zalaze u područje izrazite nesigurnosti. Njihova učenja zaista djeluju kao da posjeduju filozofsku snagu i da pogađaju esencijalno pitanje bivstva, međutim, problem leži u odsutnosti baš onog čija je suvišna prisutnost njihove suparnike sprječavala da budu na pravom misaonom tragu. Zagovornici filozofske relevantnosti svoje gledište temelje na zanemarivanju onoga što im je neposredno dano i često odbijaju prihvatiti izvjesne činjenice o svijetu. Sve dok odnos »relevantnost-egzaktnost« (evidencija) bude promatran kao međusobno isključiv, ne postoji mogućnost izlaska suvremenih filozofskih tokova iz očigledne konfuzije koja se javlja nerazumijevanjem danog odnosa.

»Glavni grijeh stare ontologije leži u njenim stalnim pokušajima da identificira biće kroz njegove razne sadržaje i manifestacije. «24 Ono što bi, prema Hartmannu, trebalo suprotstaviti tim nepotpunim promatranjima svijeta je učenje o podjednakom prihvaćanju svih slojeva bivstva. Naravno, to ne treba shvatiti kao pokušaj izjednačavanja anorganskog, organskog, duševnog i duhovnog u smislu 
stvaranja neke vrste »blok-svijeta«, odnosno brisanja granica između njih (što četvrti zakon raslojavanja — zakon distance — i onemogućava). Ključ je u raspoznavanju njihovih neospornih granica, ali i prihvaćanju međusobnih veza, koje se možda najbolje mogu opisati pomoću već spomenutih zakona raslojavanja. Dakle, svaki sloj posjeduje neovisnost, ali pri sagledavanju realnog svijeta uvijek se moraju uzimati u obzir sva četiri. U suprotnom ontologija ostaje ležati na istim pogreškama, s kojima se pokušavala boriti stoljećima unatrag.

Laying the Groundwork for a »New Ontology in the Philosophy of Nicolai Hartmann as a Criticism of Non-Integral Philosophical Systems

Strahinja Đorđević*

\section{Summary}

The aim of this paper is to study the significance of Nicolai Hartmann's contribution to ontology and, furthermore, to point out the consequences of his laying the groundwork for a »new ontology « which fact may be interpreted as a direct criticism of certain exceptionally well-represented philosophical perspectives up until his time; also, however, of new trends which escalated in philosophical circles in the period of Hartmann's creative productivity. We encounter in Hartmann's work $\gg$ New Ways of Ontology" an explanation of the real world derived from layers and categories of being. To his way of thinking, the errors of many of the contemporary philosophical approaches consist in giving preference to one layer of the real world at the expense of others, which results in the development of a reductionist perspective; furthermore, it can cause teleology to evolve into a closed system, something advocated by those who give preference to the highest, that is, the spiritual layer. One consequence of the cited conflicting views is a disagreement regarding the issue of what renders a philosophical perspective acceptable, and so the dispute ensues as to whether acceptance of a philosophical system requires that the criteria of relevance and exactness prevail. Since discord arises indirectly from giving preference to one layer with respect to other layers of the real world, both perspectives appear to be erroneous.

Key words: Nicolai Hartmann, real world, being, ontology, layers, categories, laws

* Strahinja Đorđević, mag. fil., Doctorand at the Faculty of Philosophy in Belgrade. Address: Čika Ljubina 18-20, 11000 Beograd, Serbia. E-mail: boostergold@hotmail.rs 